\title{
St Lawrence Seaway: Eastern Great Lakes, the Niagara River and Welland Canal Replacement, Maintenance and Protection
}

\author{
Kenneth R. Olson*, Cory D. Suski \\ Department of Natural Resources, College of Agricultural, Consumer, and Environmental Sciences, University of Illinois, Urbana, \\ Illinois, USA \\ Email: *krolson@illinois.edu
}

How to cite this paper: Olson, K.R. and Suski, C.D. (2020) St Lawrence Seaway: Eastern Great Lakes, the Niagara River and Welland Canal Replacement, Maintenance and Protection. Journal of Water Resource and Protection, 12, 778-799.

https://doi.org/10.4236/jwarp.2020.129046

Received: August 19, 2020

Accepted: September 20, 2020

Published: September 23, 2020

Copyright (c) 2020 by author(s) and Scientific Research Publishing Inc. This work is licensed under the Creative Commons Attribution International License (CC BY 4.0).

http://creativecommons.org/licenses/by/4.0/

\begin{abstract}
The Eastern Great Lakes region covers 51,000 square $\mathrm{km}$ of land, and is home to 15 million people. This region is rich in natural resources, industry and agriculture, and forms the heartland of both Canada and the United States. The development of this region has a history that is closely tied to waterways, and the development of canals that promoted growth and prosperity. The St. Lawrence Seaway connects Western and Eastern Great Lakes to the St Lawrence River and the Gulf of Saint Lawrence. The New York State Canal and the St. Lawrence Seaway were linked by the Oswego canal and provided a shorter route for cargo via barges to New York City. The New York State (NYS) Barge Canal and the St. Lawrence Seaway provided pathways for the settlement of the Eastern Great Lakes. Lake Erie drains into Lake Ontario via the Niagara River but the river was not navigable due to the obstacles of Niagara Falls and the Niagara Escarpment. Until the 1820s ships could not travel into Lake Erie. It was not possible to engineer a bypass of Niagara Falls with a series of locks due to the $100 \mathrm{~m}$ high Niagara escarpment. This escarpment obstacle to Niagara River navigation was overcome in 1829 with the completion of the first of four Welland Canals with locks 40 kilometers west of the Niagara River through the glacial till and alluvium that overlays the Niagara Escarpment. This permitted ocean going ships to enter Lake Erie and to continue on to Lake Michigan, Lake Huron and Lake Superior. The Eastern Great Lake shorelines, river banks and canals are actively eroding as a consequence of high surface water levels and flooding. The settlement of millions of people into the Eastern Great Lakes via the NYS Barge Canal and St. Lawrence Seaway migration pathways have created environmental and natural resource risks and challenges. These challenges and risks include deterioration of the Fourth Welland Canal and the need to replace it with the Fifth
\end{abstract}


Welland Canal, industrial and urban wastewater disposal, shoreline, river bank and canal erosion as results of high water levels, the building of structures on the shoreline banks, invasive species and flooding.

\section{Keywords}

Horseshoe Fall, Lake Erie, Lake Ontario, Niagara Escarpment, Niagara Falls

\section{Introduction}

The Eastern Great Lakes Basin consists of two Great Lakes, Lake Erie and Lake Ontario, and the Niagara River (Figure 1 and Figure 2) and the surrounding

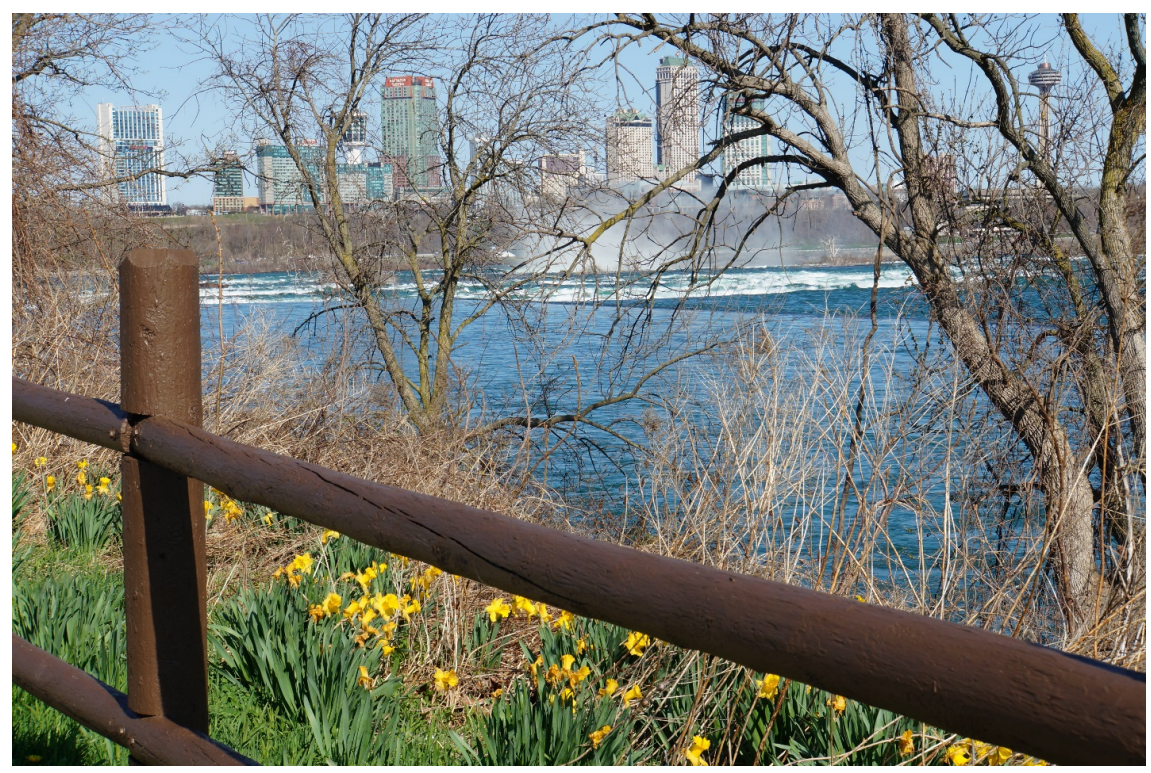

Figure 1. Niagara River fast flowing and just above the Canadian Horseshoe Falls.

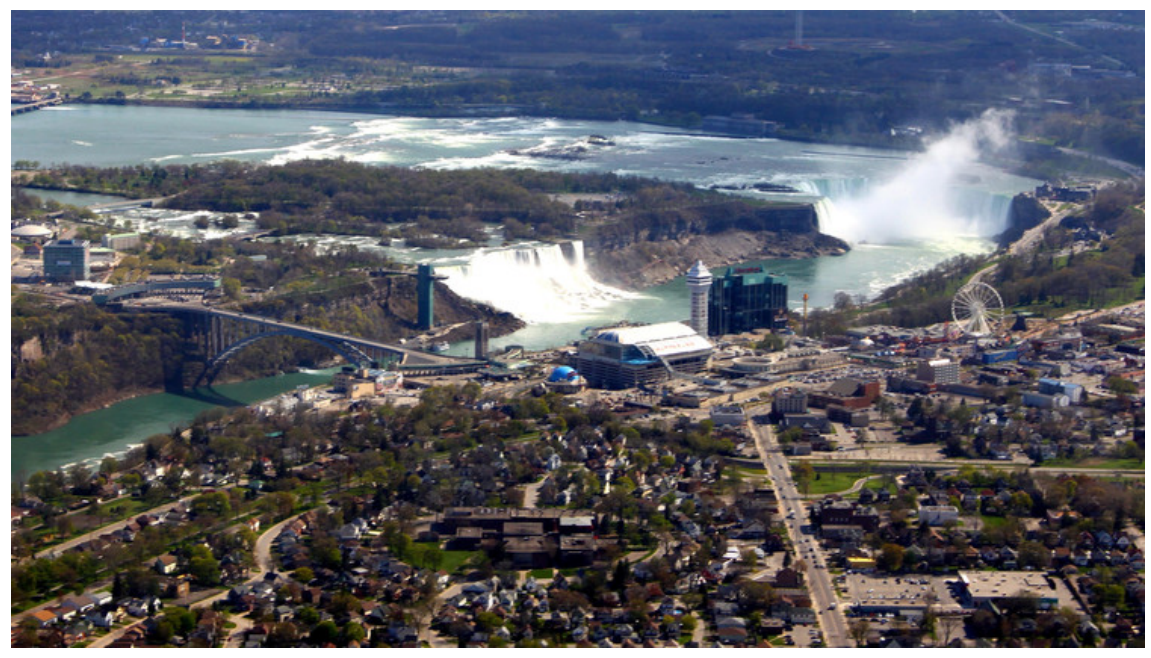

Figure 2. Aerial view of the Niagara River, Canadian Niagara Horseshoe Falls, American Niagara Falls, the gorge and City of Niagara Falls is in the background. 
watershed lands. These basins are located in the US states of Indiana, Michigan, Ohio, Pennsylvania and New York and the Canadian provinces of Quebec and Ontario [1]. The adjacent watersheds are interconnected by a sequence of rivers, lakes, straits, and canals that drain to the Atlantic Ocean via the St. Lawrence River [2]. This watershed has only one natural outlet, the St. Lawrence River that naturally flows into the Gulf of Saint Lawrence. There are more than 15 million people living in the Eastern Great Lakes basin and the area includes the United States cities of Detroit, Toledo, Cleveland, Erie, Buffalo (Figure 3) and Rochester, all of which are located on the shores of the Eastern Great Lakes [3]. Overall, the Great Lakes Basin is controlled by the Binational Great Lakes Commission. Each individual Great Lake watershed multiple sub-basins is shown in (Figure 3) [4]. The primary objective of this paper is to document the environmental risks to the Eastern Great Lakes, the Niagara River and the Welland Canal and to provide a solution to the current deteriorating Welland Canal that needs to be replaced in the next 10 years. The environmental challenges of this region, which require mitigation, include the replacement of the current deteriorating Welland Canal, navigation of the Niagara River, disposal of treated and untreated waste, water pollution, shoreline, river bank and canal erosion accelerated by high water levels, and buildings on the Eastern Great Lakes shoreline and Niagara River banks, invasive species, and flooding.

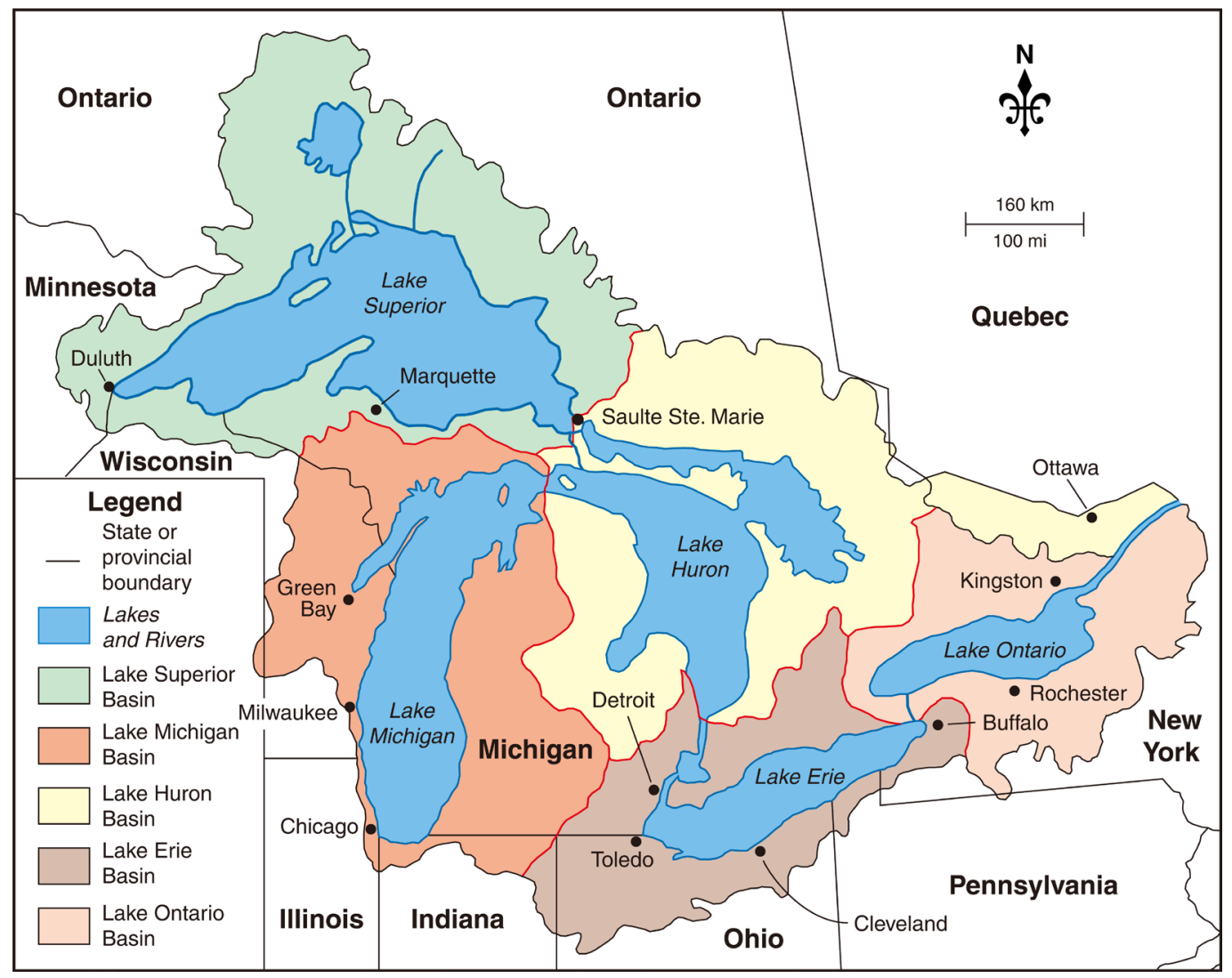

Figure 3. Great Lakes Basin and individual lake sub-basin map. Map by Mic Greenberg. Permission to re-print map from JWARP [5]. 


\section{Study Location}

\subsection{Geology of the Great Lakes}

During the Precambrian (4.5 to 0.54 billion years ago), magma created the intrusive granites of the Canadian Shield. During the Wisconsin glaciation 10,000 years ago, the area was covered with a $2 \mathrm{~km}$ thick ice sheet [1]. The land shape was carved by the advance of the ice sheet. The meltwaters left gravel, sand, clay and boulders deposited on the lake plain. At the end of the last glacial period about 14,000 years ago, the Eastern Great Lakes began to form as ice started melting and continental glaciers retreated northward [2].

About 200,000 years ago, the Lake Erie basin was an east-flowing river. This ancient drainage system was destroyed and carved out by the first major glacier [3]. The Lake Erie and Lake Ontario basins were cut by glacial ice advancing through the ancient river valley deepening and enlarging the lowlands [1]. Glaciers carved deeper on the eastern side of Lake Erie, which was soft shale. The western side of the lake was underlain by hard carbonate rocks composed of dolomite and limestone.

\subsection{Soils of Ontario, Canada}

The predominant portion of the central Ontario Zone includes most of the prime agricultural lands in Canada (Figure 4). This zone is the fastest growing urban region of the country (Figure 5). The central Ontario Zone and subject to land use conversion from agricultural land. Ontario was initially an agrarian society as a result of the presence of most of the prime agricultural soils. Other Canadian lands, such as the Canadian Shield Zone were difficult to farm due to the shallow to bedrock soils [5]. The most successful settlements were on the

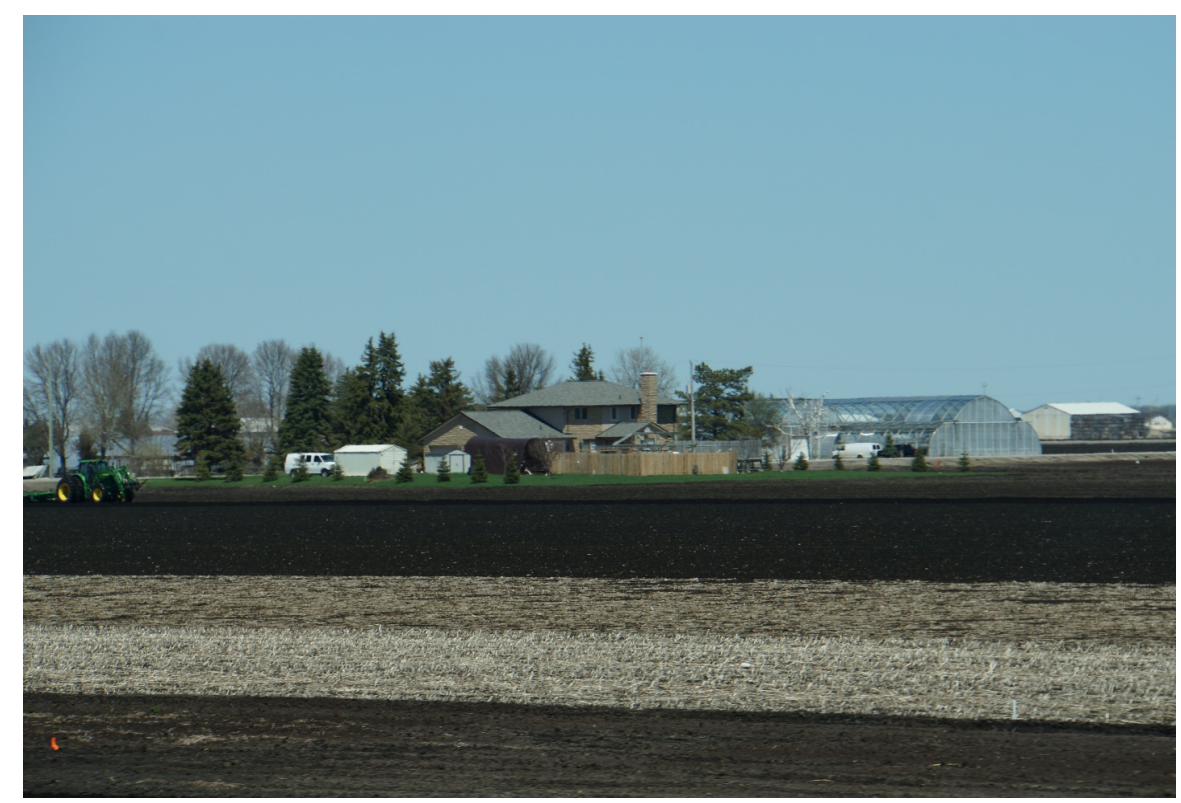

Figure 4. Prime agricultural lands along the Welland Canal and between Lake Ontario and Lake Erie. 
prime agricultural areas along the St. Lawrence River. These agricultural communities attracted service industries. Most of the prime agricultural land is located south of the Canadian Shield [6] and along the Lake Ontario shoreline and southwestern Ontario to the west of Lake Ontario and north of Lake Erie (Figure 5). This Canadian region also has the highest temperatures for plant growth.

\subsection{Lake Ontario}

Lake Ontario has both the lowest elevation (Figure 6) and is the farthest east of the Great Lakes. The Lake Ontario name was derived from an Iroquois word meaning "beautiful lake". Since 1000 B.C. and after the last Wisconsin glaciation event, Native American tribes inhabited the Great Lakes region. The Hopewell culture was visible around 1000 A.D. [7].

In 1615, Etienne Brule, a French explorer, discovered Lake Ontario, which was first called Lake St. Louis in 1632. However, on a Sanson map in 1656, it remained Lac de St. Louis. In 1660 Creuxius gave it the name Lacus Ontairus, meaning beautiful lake. During the $17^{\text {th }}$ and early $18^{\text {th }}$ centuries, the French built forts along the south shore of Lake Ontario. The lake has rich history of trade and commerce. After the War of 1812, canals including the Erie, Champlain and Oswego canals, were built and utilized by steamships. Lake Ontario was a commerce and transportation hub until railroads were built [8].

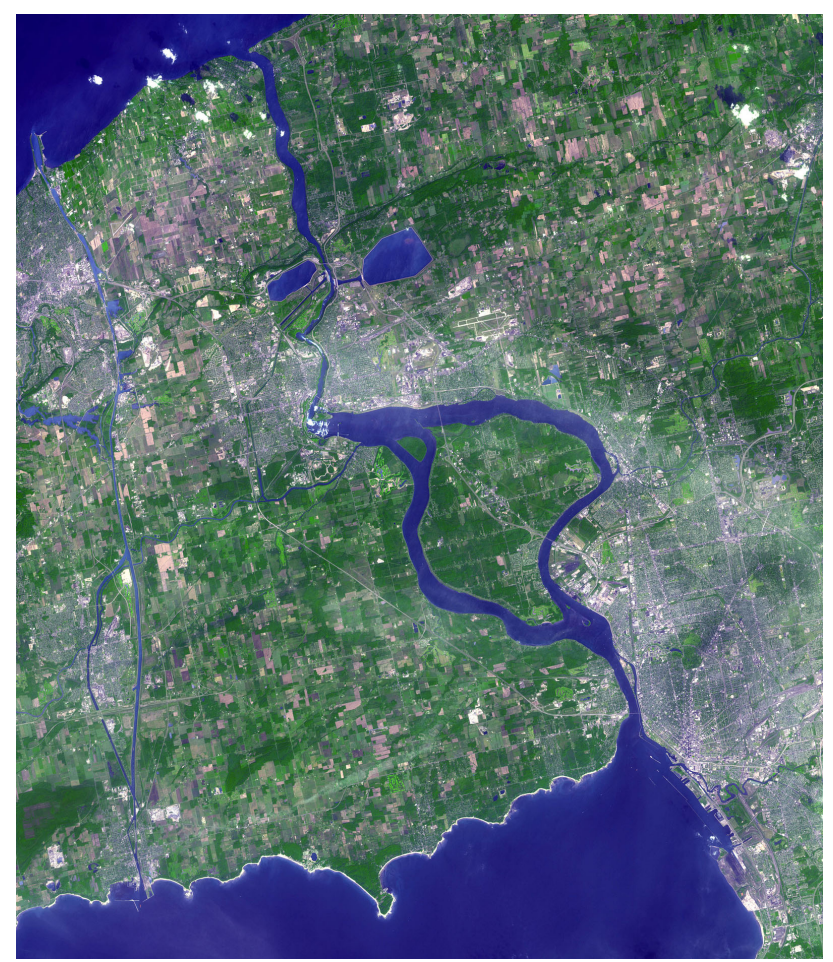

Figure 5. Satellite image of the Niagara River between Lake Ontario and Lake Erie. The Welland Canal is approximately $40 \mathrm{~km}$ to the west of Niagara River. Niagara Falls is on the big bend of the Niagara River. Permission to re-print the photograph was provided by NASA Visible Earth program for satellite photograph. ASA/GSFC/MITI/ERSDAC/AROS/ Japan Aster Science Team. 
The St. Lawrence River connects the Gulf of Saint Lawrence with Lake Ontario (Figure 3) [6]. Lake Ontario, with an $18,960 \mathrm{~km}^{2}$ surface area, is the smallest of all the Great Lakes and has the lowest elevation of $74 \mathrm{~m}$ (Figure 6). However, Lake Ontario holds 4 times more water than Lake Erie. In 2017, the water levels of Lake Ontario reached their greatest height in the last 100 years. This resulted in severe erosion and massive flooding [5]. The St. Lawrence River provides the only natural outlet for the entire Great Lakes Basin. Lake Ontario is the eastern most Great Lake and is below the Niagara Escarpment (Figure 7) at the base

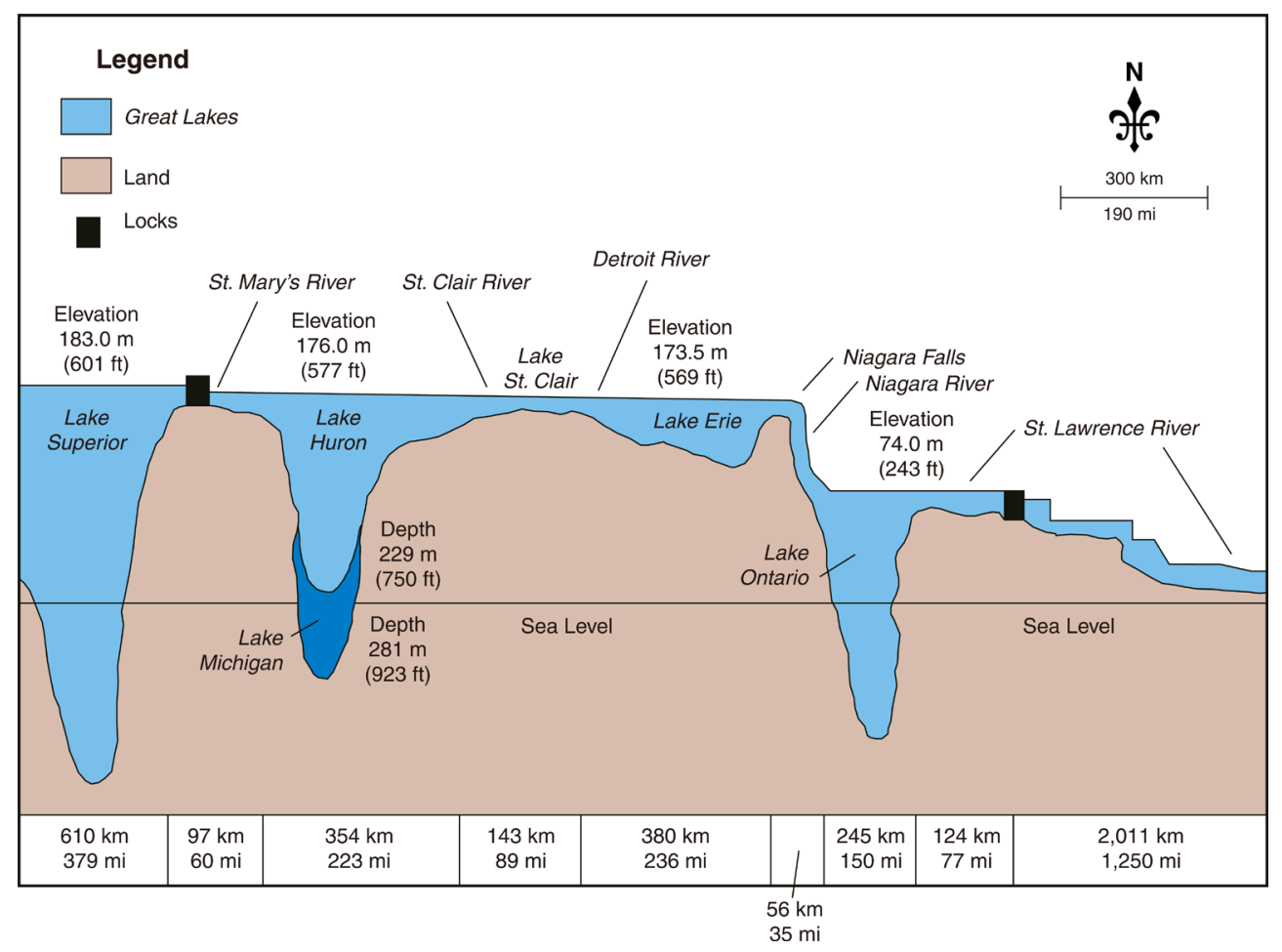

Figure 6. Great Lake depths and elevations. The waterways between the Great Lakes are identified. Map by Mic Greenberg.

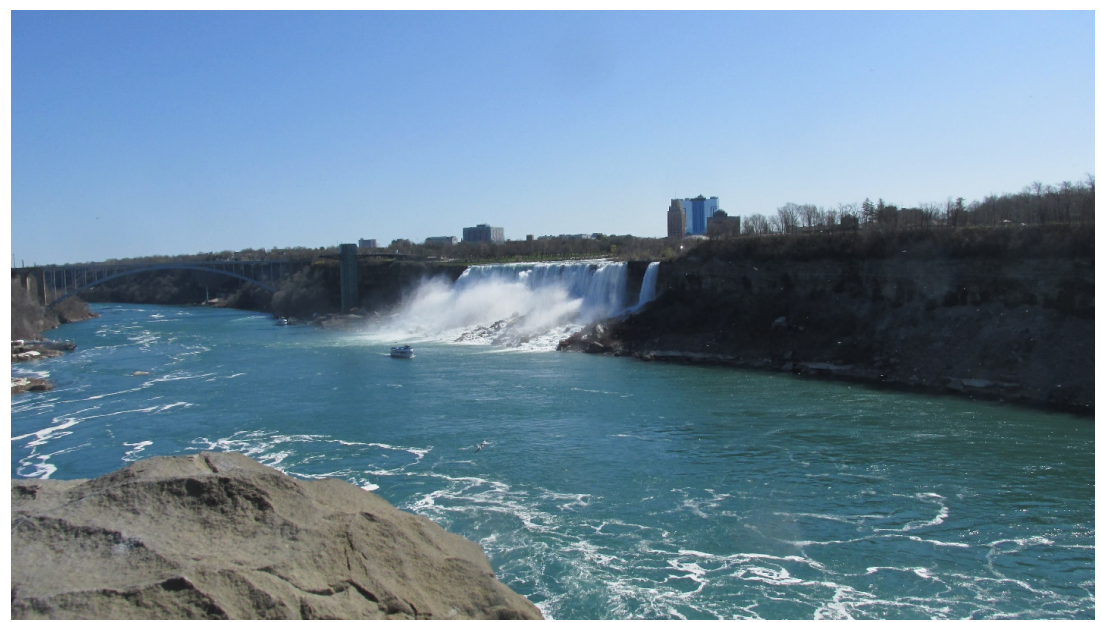

Figure 7. The Niagara Escarpment and American Niagara Falls on the Niagara River. The City of Niagara Falls is in the background. Photograph taken by Lois Wright Morton. 
level of the falls. Niagara Falls and the Niagara Escarpment were an obstacle to navigation into the upper Great Lakes until the Trent-Severn Waterway and the Welland canals were built to permit ships, boats and barges to pass to the west of the Niagara River and across the Niagara Escarpment. Lake Erie flowed naturally into Lake Ontario via the Niagara River and later partially through the Welland Canal. The canal, located $40 \mathrm{~km}$ west of Niagara River, provides a navigation channel between Lake Ontario and Lake Erie. Lake Ontario is bordered by the Province of Ontario and New York State [1].

\subsection{Lake Erie}

Lake Erie, named by the Erie tribe, is the $4^{\text {th }}$ largest Great Lake in terms of surface area, and has an elevation of $173.5 \mathrm{~m}$ (Figure 6). It is the smallest lake by volume, shallowest and southernmost. The deepest point in Lake Erie is only 64 $\mathrm{m}$ (Figure 6). Lake Erie's northern shore is in the Canadian province of Ontario [1]. The southern shore is Pennsylvania, Ohio, Michigan and New York on the west end of the lake. The primary natural outlet for Lake Erie is the Niagara River which flows over Niagara Falls (Figure 7).

The Niagara River provides hydroelectric power (Figure 8) to Canada and the United States, and it spins huge turbines near Niagara Falls at Lewiston, New York and Queenstown, Ontario. The Welland Canal now provides an additional human-made outlet for Lake Erie water flowing into Lake Ontario. The Welland Canal diverts water via a series of 8 locks for ships to travel from St. Catharines on Lake Ontario to Port Colborne, Ontario with an elevation difference of $100 \mathrm{~m}$ (Figure 6). The Welland Canal avoids Niagara Falls and connects Lake Erie to Lake Ontario for navigation. Lake Erie has a surface area of 25,667 $\mathrm{km}^{2}$. The largest towns on Lake Erie are Buffalo, Erie, Toledo and Cleveland [2].

The St. Lawrence River provides the Great Lakes an outlet to the Gulf of Saint

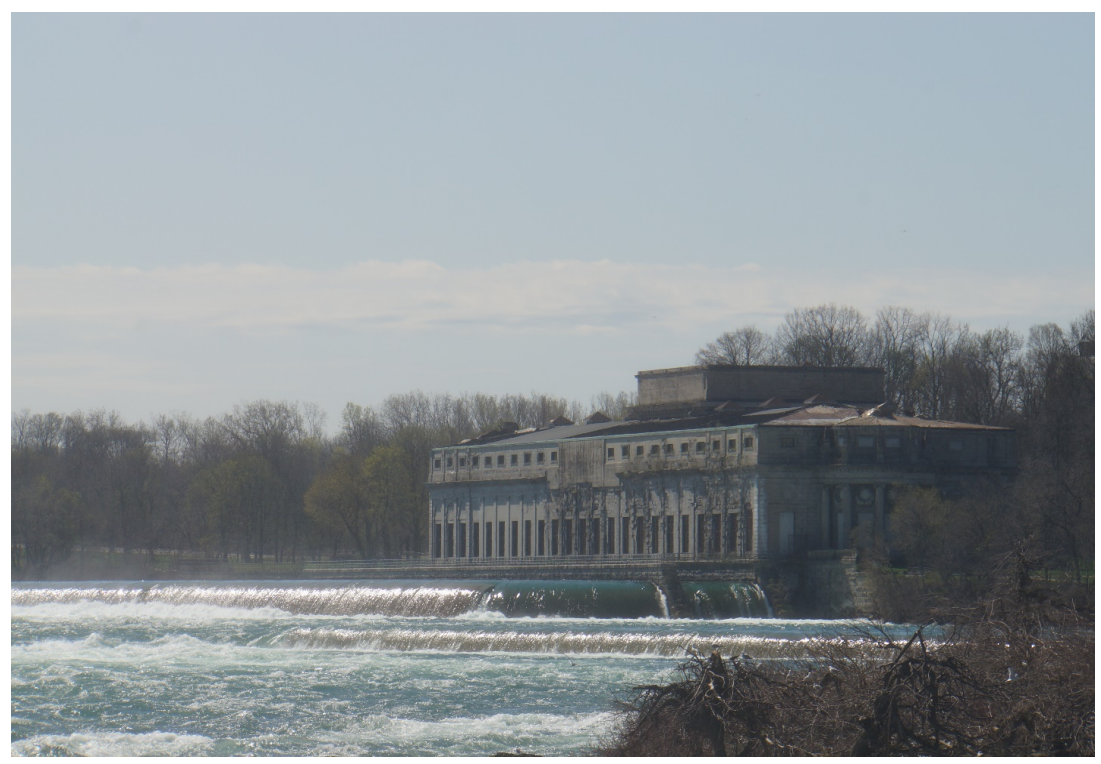

Figure 8. Canadian hydroelectric power plant on Niagara River above Niagara Falls. 
Lawrence and the Atlantic Ocean [6]. The Thousand Islands region (Figure 9), an archipelago of nearly 2,000 islands, lines the United States and Canadian border. Thus, the western section of the Lake Erie basin is only $7.6 \mathrm{~m}$ deep but rich in nutrients, including nitrogen, and fish. The rich nutrients have caused periodic algae blooms [9]. Lake Erie (Figure 6) was carved where the glacial ice was thinner and lacked carving and erosive power. There were as many as 3 glacial events in the Eastern Great Lakes basin. After the last of these glacial events between about 13,000 and 12,000 years ago, Lake Warren existed [10]. The lake was deeper than Lake Erie and had a shoreline $13 \mathrm{~km}$ to the south. The shorelines of these ancient lakes left behind sand ridges that were higher than the adjacent swamps and were used as pathways for aboriginal groups and later pioneers. These trails were eventually paved to become US Route 20 east of Cleveland and U.S. Route 30 west of Delphos. The sandy beach ridges and ancient sand dunes formed the Oak Region in Northwest Ohio. The sandy dry lake bed soils were not able to support trees except for oaks that formed a rare oak savanna. The environmental health of Lake Erie has deteriorated for decades; issues include industrial and urban pollution, overfishing, algae blooms [9] and eutrophication.

\subsection{Niagara River}

The $58 \mathrm{~km}$ Niagara River flows over Niagara Falls to Lake Ontario. The Niagara River (Figure 5) is part of the international border between New York in the United States, and Ontario in Canada. The word "Noagara" is thought to be derived from the Niagagarega people who occupied the Niagara River area, and the native Neutral Confederacy was noted on the $17^{\text {th }}$-century French maps [7].

Niagara Falls has moved $11 \mathrm{~km}$ upstream during the last 12,000 years (Figure 2). The erosion of the Niagara Escarpment by the Niagara River has created a gorge down river from Niagara Falls [11]. The Niagara Falls water drops $100 \mathrm{~m}$ (Figure 10) and is used to generate hydroelectricity. The diversion of water to

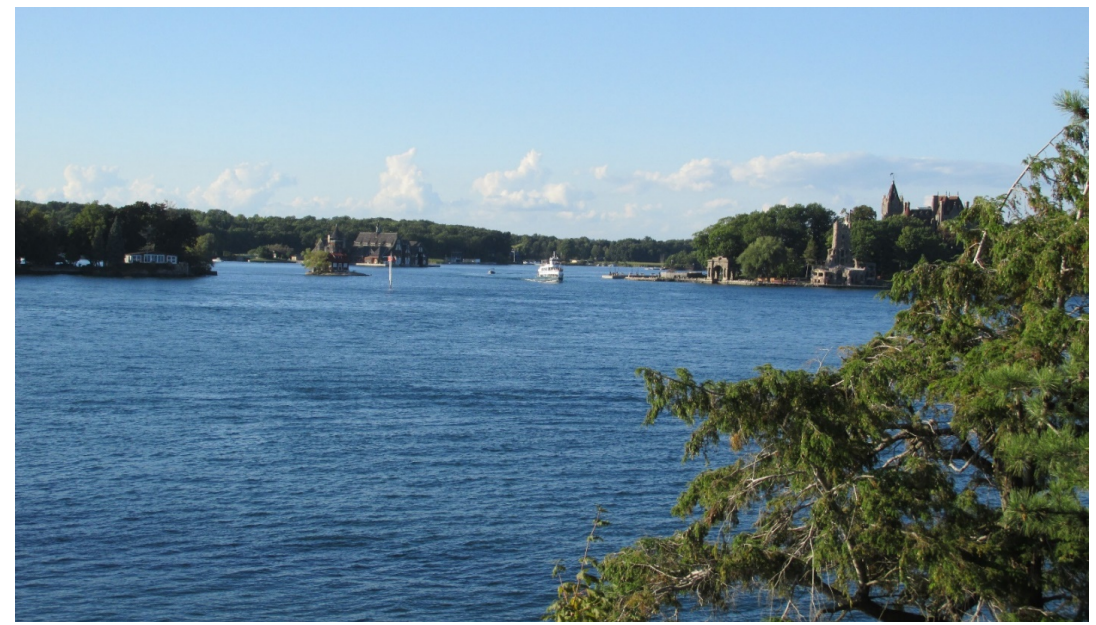

Figure 9. Thousand Islands on St. Lawrence River east of Lake Ontario and near Kingston, Canada. 
generate electricity has reduced the erosion rate. The Sir Adam Beck Hydroelectric Power Stations, built in 1922 and 1954 on the Canadian side (Figure 8), and Robert Moses Niagara Power Plant (1961) on United States side, generate 4.4 gigawatts of electricity.

In the $17^{\text {th }}$ century, Father Louis Hennepin, a French explorer, discovered the Niagara River and two large islands, Navy Island and Grand Island (Figure 5). The Niagara River bank is home the oldest railroad in United States. An inclined wooden tramway (Figure 11) was built by John Montresor in 1764 and called

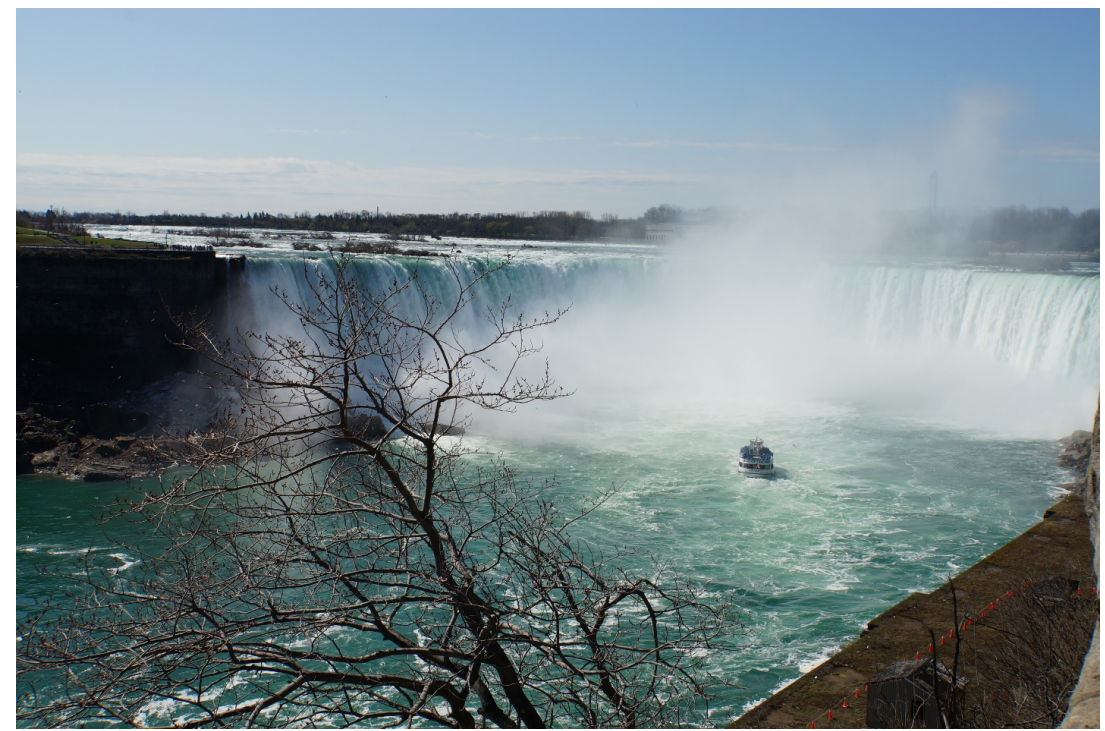

Figure 10. Canadian Niagara Horse Shoe falls on the Niagara River separating Canada from United States. The Maid of the Mist (US) is approaching misty Niagara Falls. Photograph taken by Lois Wright Morton.

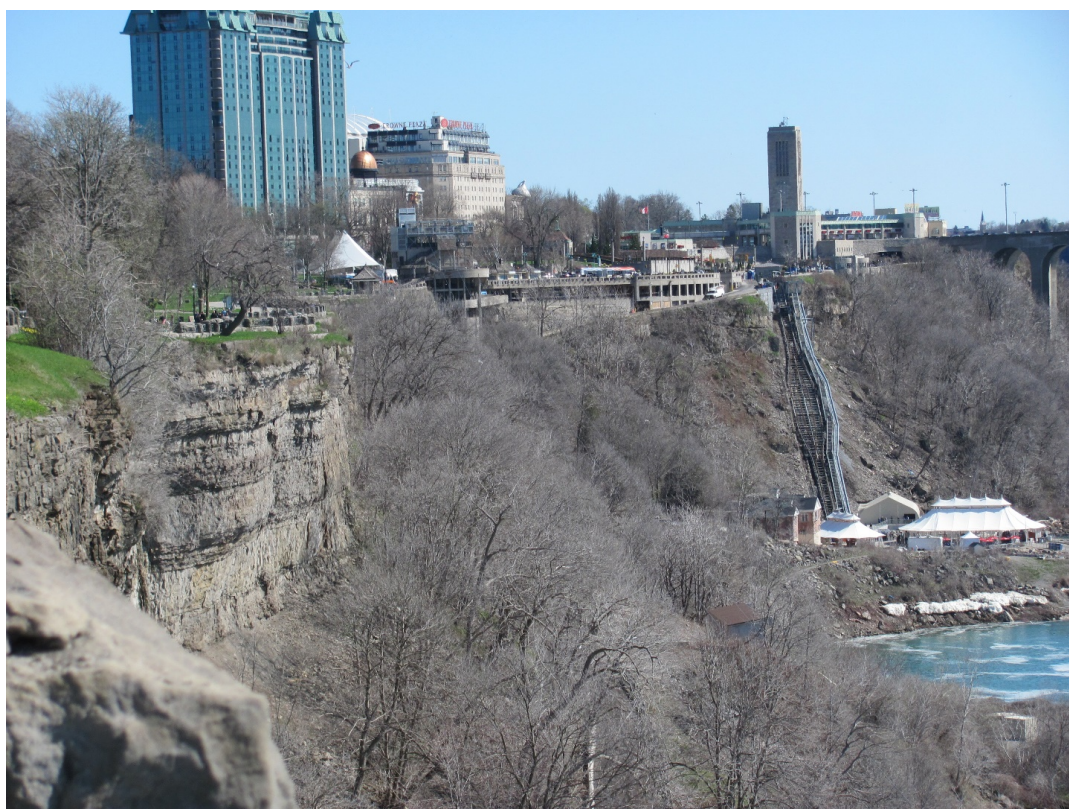

Figure 11. Tram line to the bottom of the escarpment on the United States side of the Niagara River. The City of Niagara Falls is in the background. 
the "The Old Lewiston Incline" and the "The Cradles" [12].

\subsection{Welland Canal}

The Welland Canal (Figure 12) in Ontario, Canada was built in between 1824 and 1829 and now connects Lake Ontario with Lake Erie [13]. The $43 \mathrm{~km}$ canal crosses the Niagara peninsula from Port Colborne to Port Weller in St. Catharines. The Welland Canal (Figure 13) was modified and expanded four times. The canal now has 8 locks (Figure 14) which enable ships to ascend and descend the Niagara Escarpment and by-pass Niagara Falls [13]. These locks accommodate ships up to $23.8 \mathrm{~m}$ in width and up to $225.6 \mathrm{~m}$ long. After a fourth iteration of a canal around the Niagara Falls (Figure 15), the Welland Canal passes about 3,000 ships that transported an average of 40,000,000 tons of cargo

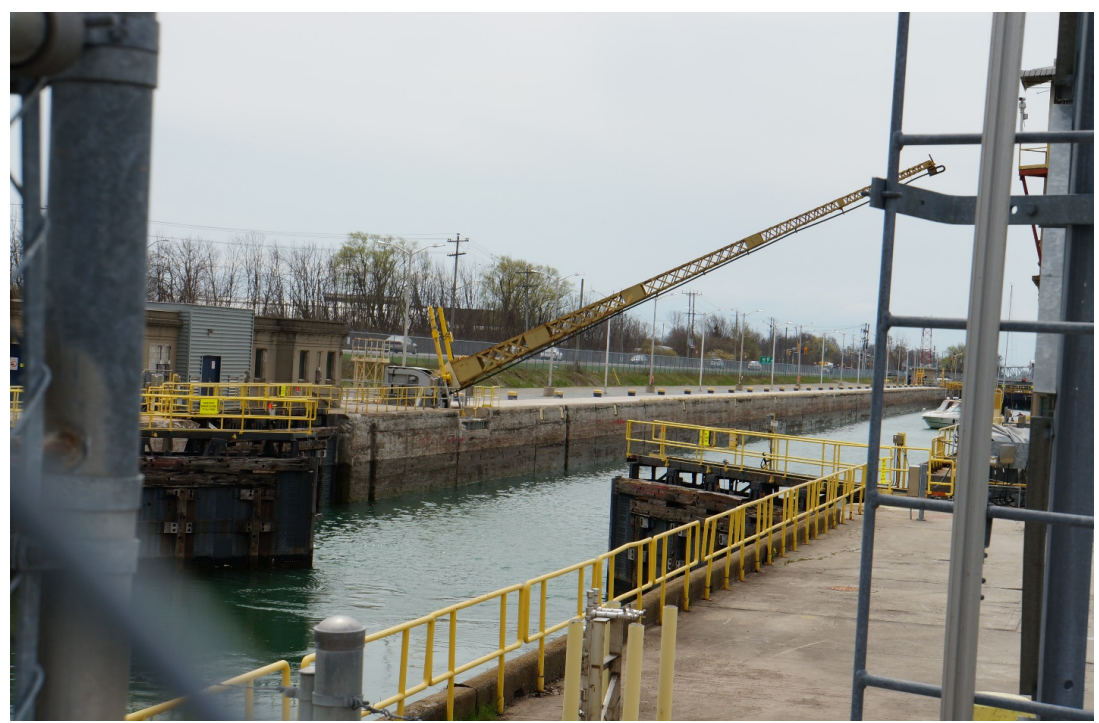

Figure 12. Welland lock with gates open.

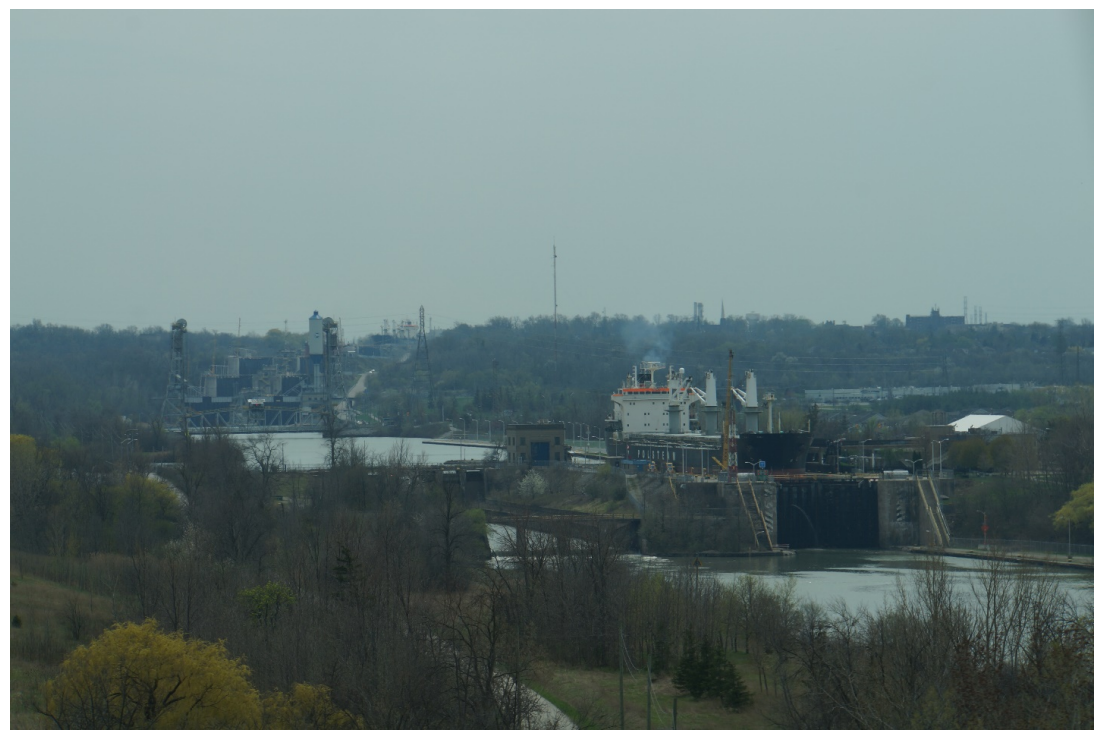

Figure 13. Ocean going ship passing through a Welland lock in a valley. 


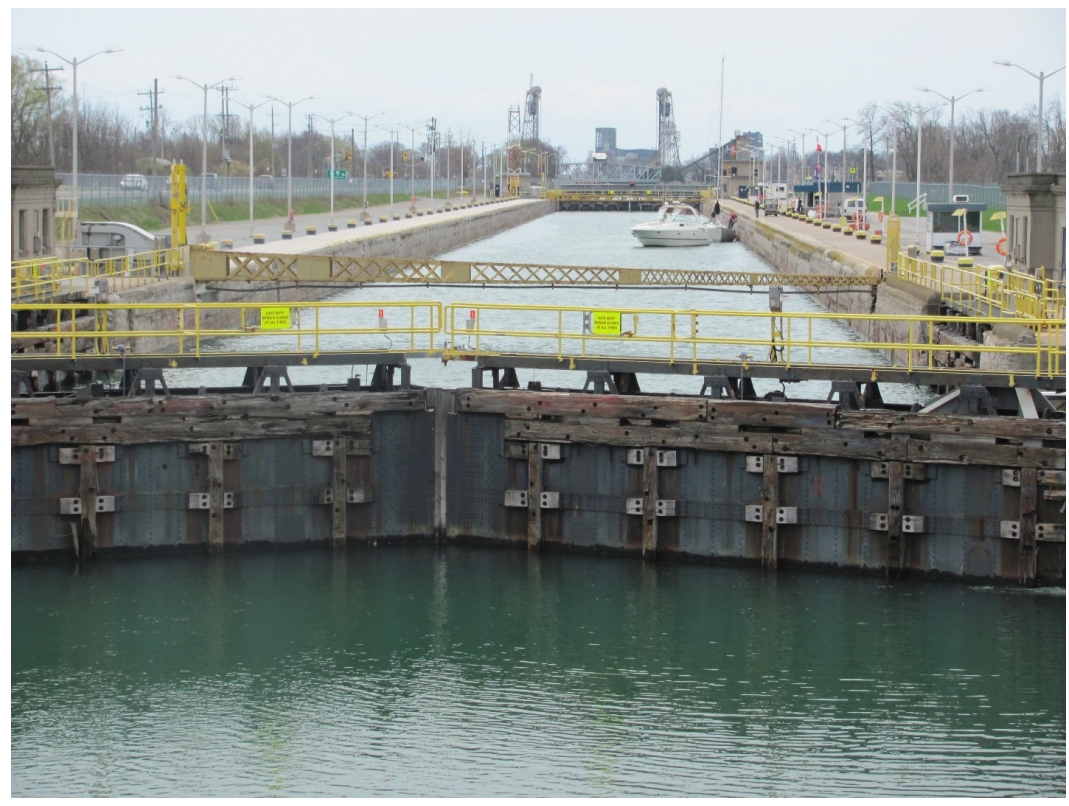

Figure 14. Welland Canal lock with recreational boat in the locks.

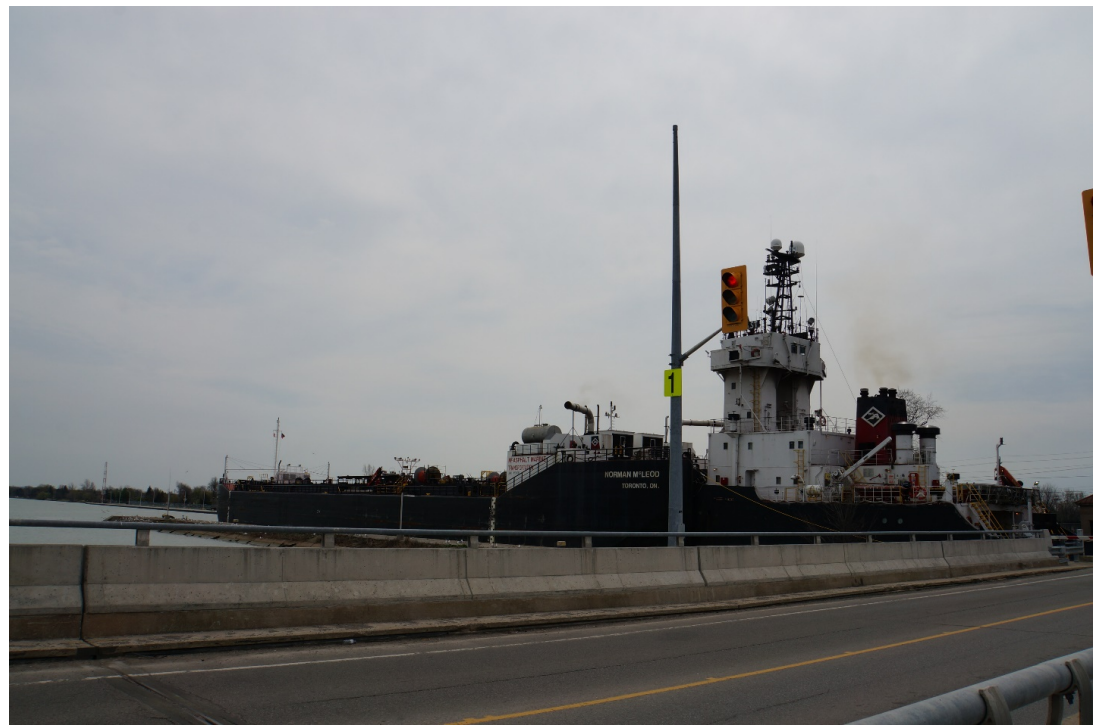

Figure 15. Ocean going ship passing through the Welland Canal after bridge was raised. The Welland Canal links Lake Ontario to Lake Erie. Photograph taken by Lois Wright Morton.

a year (Figure 16) [14].

The Welland Canal was a major factor in the growth of Toronto, Ontario. The original canal and its successors allowed goods from Great Lakes ports such as Detroit, Cleveland, Milwaukee, and Chicago, as well as other heavily industrialized areas of the United States and Ontario, to be shipped to the port of Montreal or Quebec City, where they were reloaded onto ocean-going vessels for international shipping [13]. The Welland Canal competed with, and then later eclipsed, other narrower canals in the region including the Trent-Seven Waterway. The Erie Canal, which was a barge canal that linked New York City and the Atlantic 


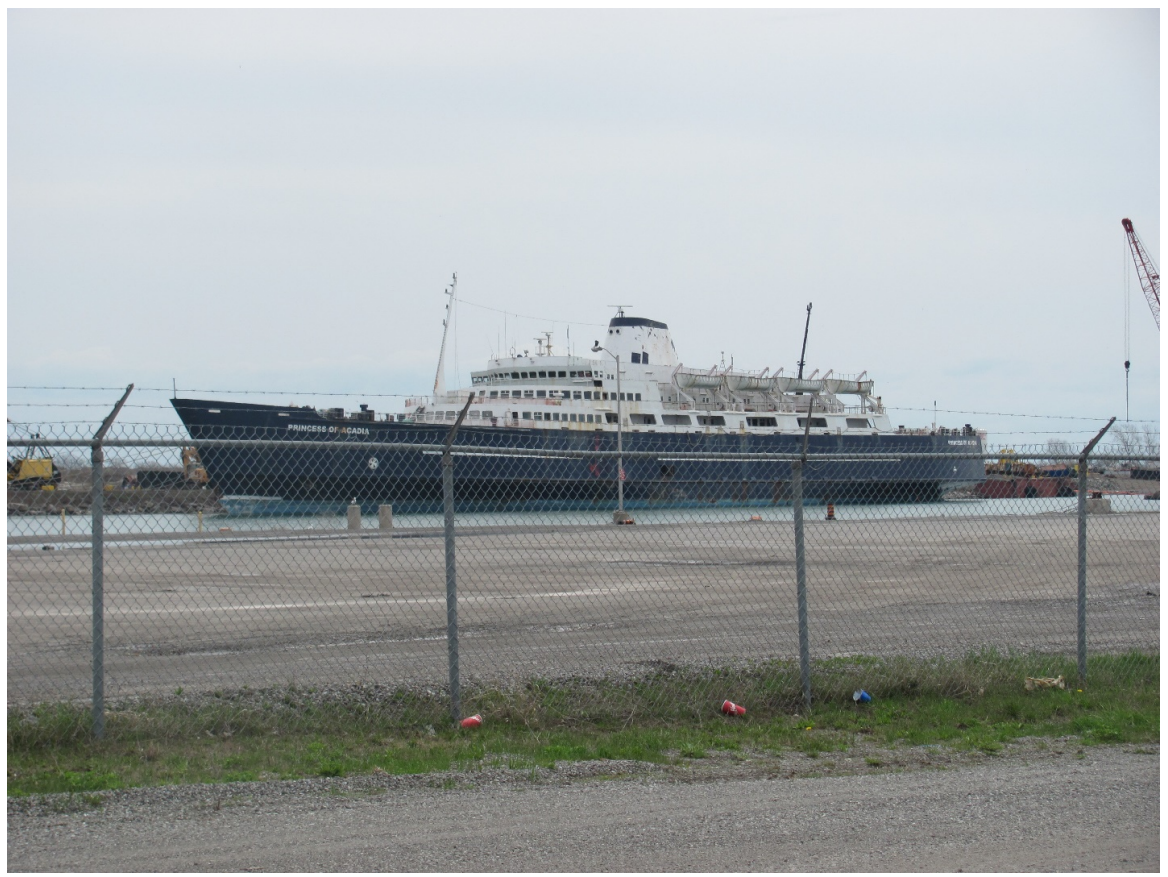

Figure 16. Ocean going ship on the Welland Canal north of Lake Erie and headed to Lake Ontario.

Ocean, and Buffalo, New York and Lake Erie, provided a shorter, more direct connection [14].

The southern Lake Erie terminus of the Welland Canal is $100 \mathrm{~m}$ higher than the northern terminus on Lake Ontario. The canal includes eight 24.4-m wide ship locks. The other seven of the locks (the "Lift" locks, Locks 1 - 7) are $233.5 \mathrm{~m}$ long and raise (or lower) passing ships between 13 and $15 \mathrm{~m}$ each. The southernmost lock, the "Guard" or "Control" lock (Lock 8), is $349.9 \mathrm{~m}$ in length (Figure 16). The Garden City Skyway, which passes over the canal, restricts the masts of ships to a maximum height of $35.5 \mathrm{~m}$ [13]. All other railroad or highway crossings of the Welland Canal (Figure 15) have either movable bridges (of the vertical lift or bascule bridge types) (Figure 17) or tunnels. The maximum permissible length of a ship in this canal is $225.5 \mathrm{~m}$. It takes ships an average of eleven hours to traverse the entire length of the Welland Canal.

\subsection{First Welland Canal}

In 1824, the Province of Upper Canada incorporated the Welland Canal Company after a petition by nine "freeholders of the District of Niagara" [13]. Construction of the canal began at Allanburg, Ontario, near the west end of Bridge No. 11. This canal opened for a trial run on November 30, 1829. The first canal ran from Port Dalhousie, Ontario on Lake Ontario south along Twelve Mile Creek to St. Catharines. From there, the canal passed over the Niagara Escarpment through Merritton to Thorold, Ontario. Originally, the section between Allanburg and Port Robinson was planned to be carried in a tunnel. However, the sandy soil in this part of Ontario made a tunnel infeasible, and a 


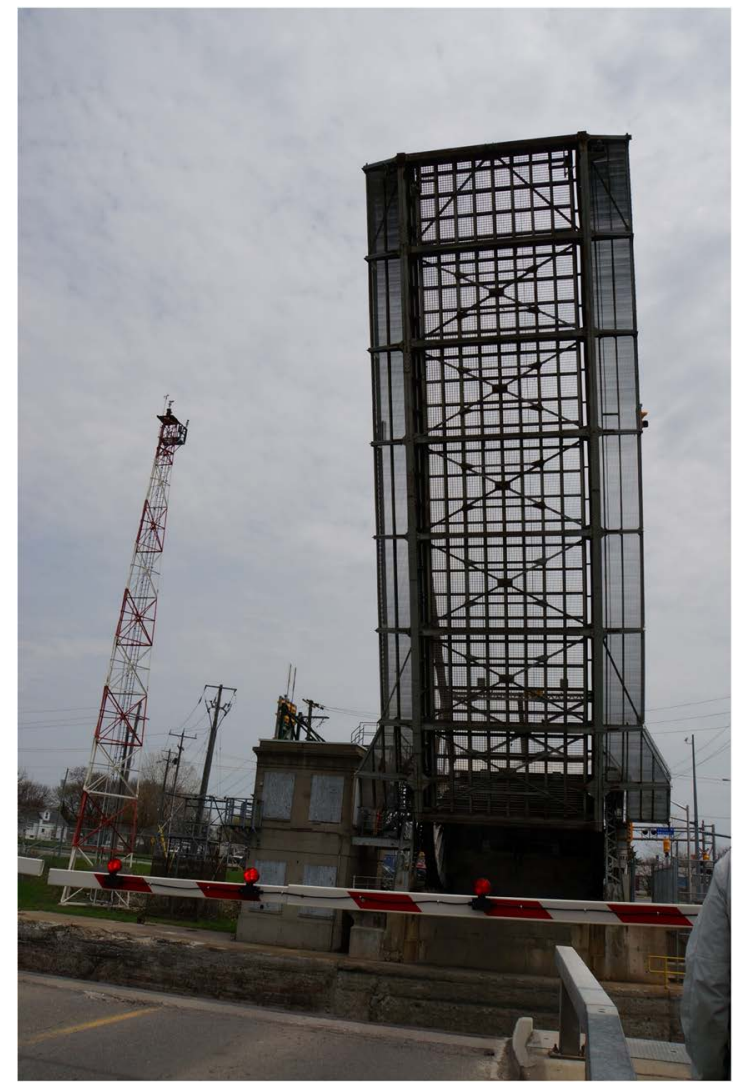

Figure 17. Raised Road Bridge to allow tall ships to pass through the Welland Canal.

deep open-cut canal was created instead. Within just a few years, the 40 wood locks deteriorated [Table 1] and, along with the increasing size of ships, led to demand for the second Welland Canal [13].

\subsection{Second Welland Canal}

In 1839, the government of Upper Canada approved the purchasing of the Welland Canal Company shares in the private canal company, in response to the private company's continuing fiscal problems as a result of the 1837 continental financial panic [13]. The public buyout was completed in 1841, and work began to deepen the canal to $2.7 \mathrm{~m}$ and to reduce the number of locks to 27 [Table 1]. By 1846, a $2.7 \mathrm{~m}$ deep path was completed through the Welland Canal, and by 1848 , that depth was extended all the way to the Atlantic Ocean.

In 1854, canal competition came with the opening of the Erie and Ontario Railway, running parallel to the original portage road. In 1859, the Welland Railway opened and ran adjacent and parallel to the canal with the same terminal points. This railway was affiliated with the canal and used to transfer cargo from the lake ships, which were too large for the canal locks, to the other end of the canal. Canallers, smaller ships, were also used to transfer cargo [12]. Consequently these locks were too small and soon had to be replaced. By 1871, the St. Lawrence River locks and canals allowed the transit of vessels $57 \mathrm{~m}$ long, $13.6 \mathrm{~m}$ wide and $2.7 \mathrm{~m}$ deep to enter Lake Erie from Lake Ontario. The St. Law- 
rence River locks were was enlarged 3 times to an eventual size of $233 \mathrm{~m}$ long, 24 $\mathrm{m}$ wide and $9.1 \mathrm{~m}$ deep.

\subsection{Third Welland Canal}

In 1887, a shorter alignment was completed from St. Catharines to Port Dalhousie (Figure 5). An enhanced feature of the third Welland Canal was the Merritton Tunnel (Figure 18), built in 1876 on the Grand Trunk Railway line, and went under the Welland canal between Locks 18 and 19. Another tunnel carried the canal over an underground section (Figure 19) of St. David's Road [14]. The route had a minimum depth of $4.3 \mathrm{~m}$ with twenty-six $82.3 \mathrm{~m}$ long by $13.7 \mathrm{~m}$ wide locks. The new locks were still too small for many ocean going ships.

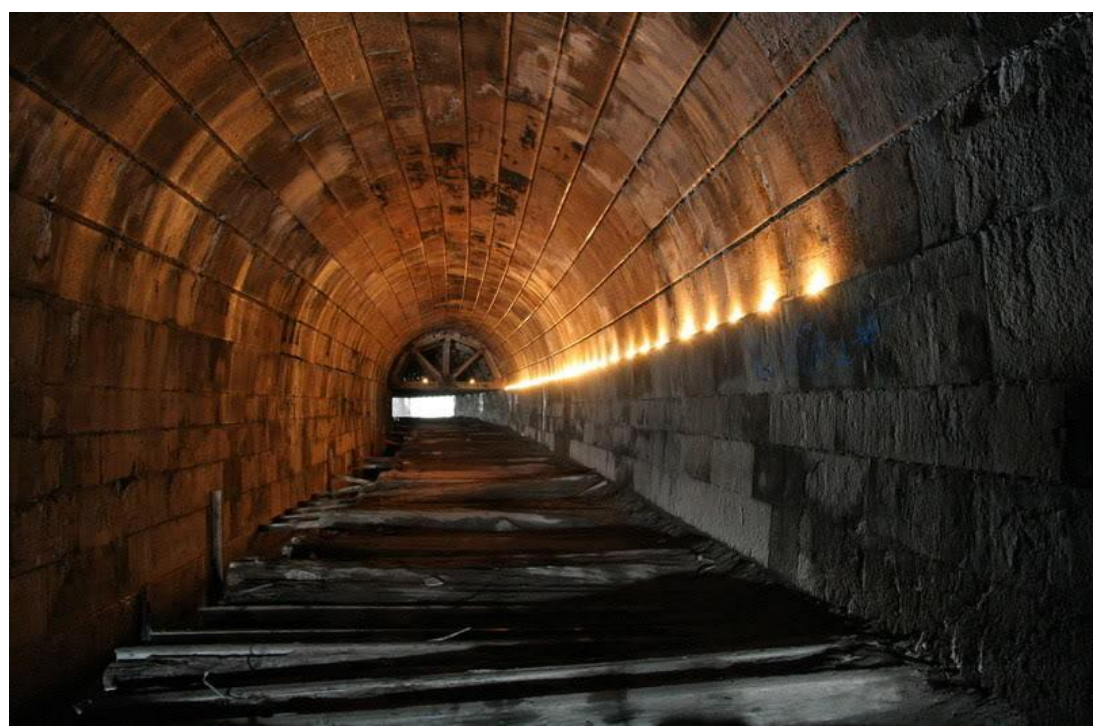

Figure 18. Old Merritton Tunnel built in 1800s and is no longer in use.

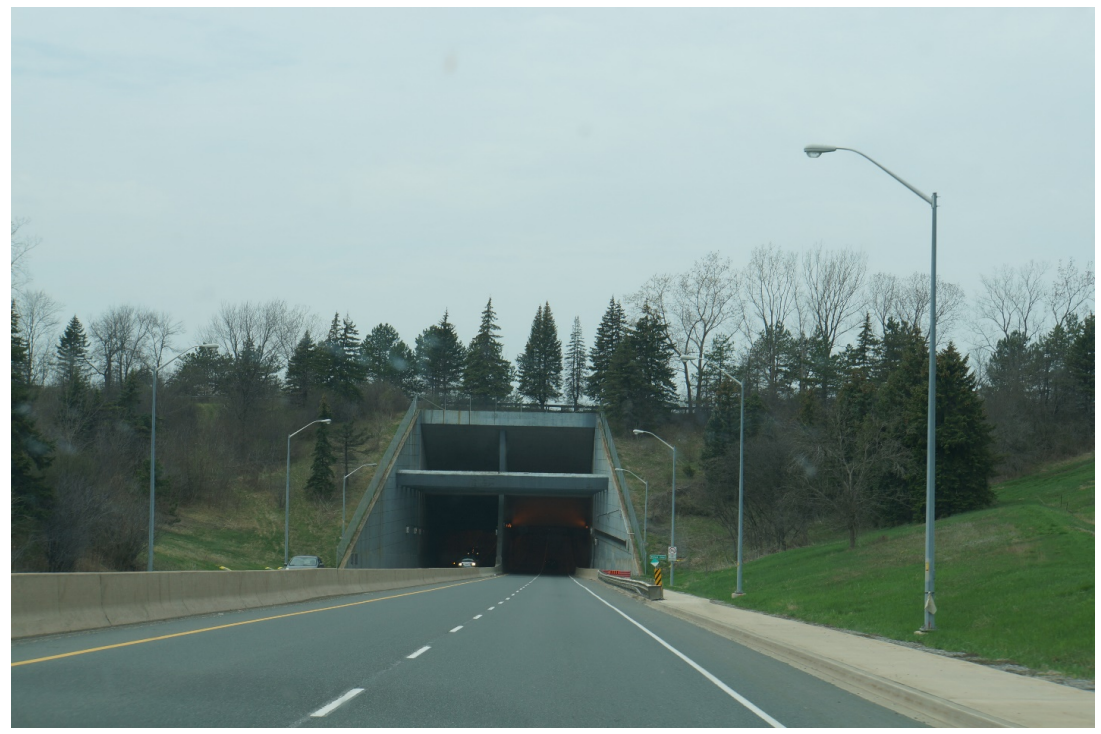

Figure 19. Highway going under the Welland Canal. 


\subsection{Fourth Welland Canal}

Construction on the fourth Welland Canal (Figure 16) began in 1913, but work was delayed from 1916 to 1919 due to a shortage of men and workers during World War I. The canal was finally completed and opened on August 6, 1932 [14]. Dredging to the planned $7.6 \mathrm{~m}$ depth was not achieved until 1935. The route was re-aligned north of St. Catharines, and now ran north to Port Weller. The current configuration of the Welland Canal has eight locks, seven at the Niagara Escarpment and the eighth one, a guard lock, at Port Colborne capable of adjusting to the varying water depths of Lake Erie. The canal depth was $7.6 \mathrm{~m}$ and had $233.5 \mathrm{~m}$ long by $24.4 \mathrm{~m}$ wide locks. This canal name was officially changed to the Welland Ship Canal. The Welland Ship Canal's "hands-free" vacuum mooring was installed locks 1 through 7 by 2017 [14].

\subsection{Welland By-Pass}

A standard canal depth of $8.2 \mathrm{~m}$ [Table 1] was adopted in the 1950s with the creation of the St. Lawrence Seaway. The 13.4-km Welland By-Pass was built between 1967 and 1972 (Figure 5), and opened for the 1973 shipping season. The by-pass provided a shorter re-alignment between Port Robinson and Port Colborne, and went around downtown Welland. All three crossings of the new alignment were built as tunnels (Figure 19) and was an aqueduct for the Welland River. At the same time, several bridges were removed and the Thorold Tunnel was built at Thorold (Figure 20).

\subsection{Fifth Welland Ship Canal (Proposed But Uncompleted)}

A Fifth Welland Canal is being planned to the east of the existing canal and

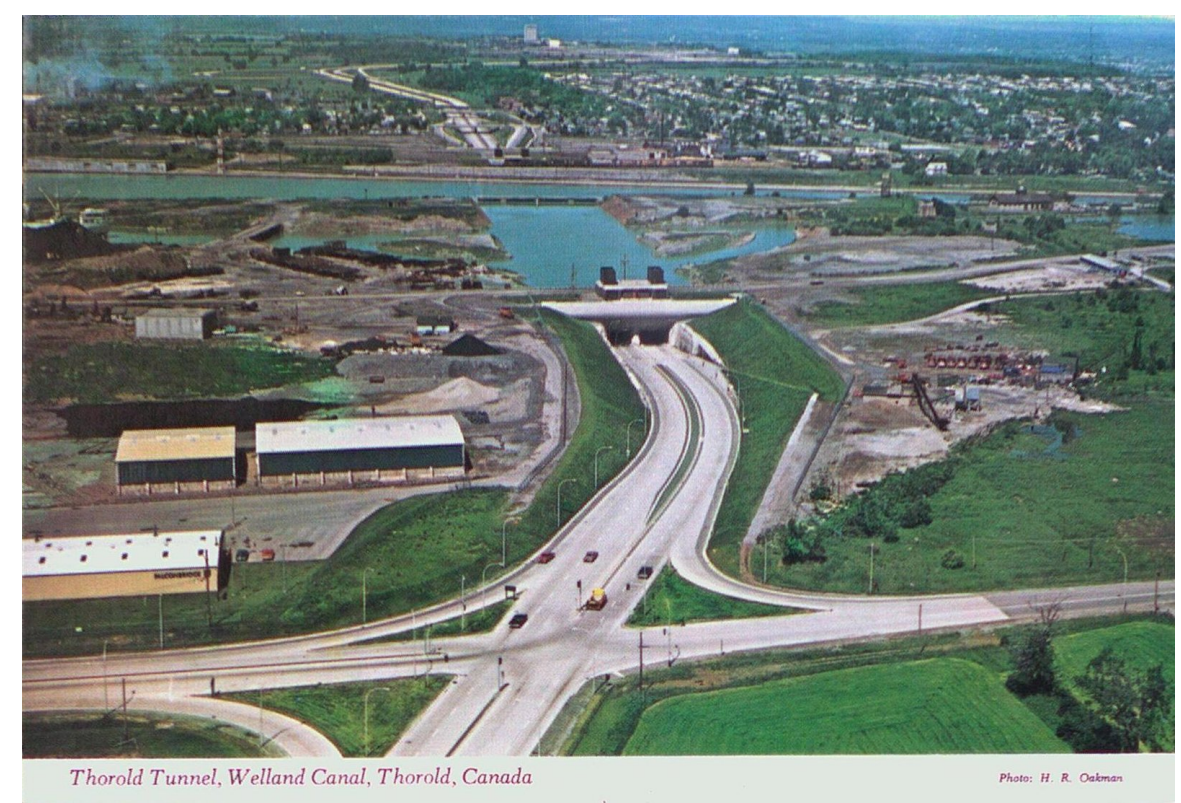

Figure 20. A modern highway passes through the Thorold Tunnel and under the Welland Canal at Thorold. 
would have crossed the Niagara Escarpment in one 'super lock'. While the design was finalized and the land expropriated, the project never advanced past the initial construction stages before being abandoned. The present Welland Ship Canal was originally designed to only last until 2030, or for 200 years after the 1830 first full shipping season. Subsequent improvements to the canal infrastructure appear to have extended the project life [13].

\subsection{Welland Canal Facts}

The Welland Canal closes in winter (January-March) when ice or weather conditions become a hazard to navigation. The shipping season reopens in spring when the waters are once again safer for navigation [14]. The historic canal facts are shown in Table 1.

\subsection{St. Lawrence Seaway}

The St. Lawrence Seaway connects all 5 Great Lakes (Figure 21) to the St. Lawrence River, Gulf of Saint Lawrence and Atlantic Ocean. The seaway was completed with the New York State (Erie Canal) canal [8] for cargo. The NYS Barge Canal and the St. Lawrence Seaway (Lake Ontario) were linked by the Oswego canal at the mouth of the Oswego River on Lake Ontario (Figure 22). The New York State Canal (NYS) System, originally named the New York State Barge Canal, was an $845 \mathrm{~km}$ canal system that included the Erie Canal and connected the Hudson River and Niagara River north of Lake Erie. Other NYS System canals included the Oswego Canal that connected the Erie Canal to Lake Ontario (Figure 22), the Cayuga-Seneca Canal that connected Seneca Lake and Cayuga Lake to the Erie Canal, and the Champlain Canal which links the Hudson River to Lake Champlain. On October, 25, 1825 the Erie Canal opened, linking Great Lakes and the Atlantic Ocean.

The Erie Canal in New York State originally ran $580 \mathrm{~km}$ from Albany, NY on the Hudson River to Niagara River and Lake Erie at Buffalo, New York [14]. It resulted in a completely navigable waterway route from New York City (Atlantic Ocean) to the Great Lakes. At this point in history, there were no steamships or railways through this region, and water was the least expensive way to ship bulk goods and huge tonnages as pack animals were limited to $100 \mathrm{~kg}$ loads. Over time, the St. Lawrence Seaway has transitioned to handle the bulk of the shipping, while the New York State (Erie) canal is now being used primarily by private recreational boaters. Only the Hudson River to Lake Champlain canal has

Table 1. Increases in size of the Welland Canal locks over time [14].

\begin{tabular}{ccccc}
\hline Canal & First (1829) & Second (1846) & Third (1887) & Fourth (1932) \\
\hline Locks & 40 & 27 & 26 & 8 \\
Width (m) & 6.7 & 8.1 & 13.7 & 24.4 \\
Length (m) & 33.5 & 45.7 & 82.3 & 261.8 \\
Depth (m) & 2.4 & 2.7 & 4.3 & 8.2 \\
\hline
\end{tabular}




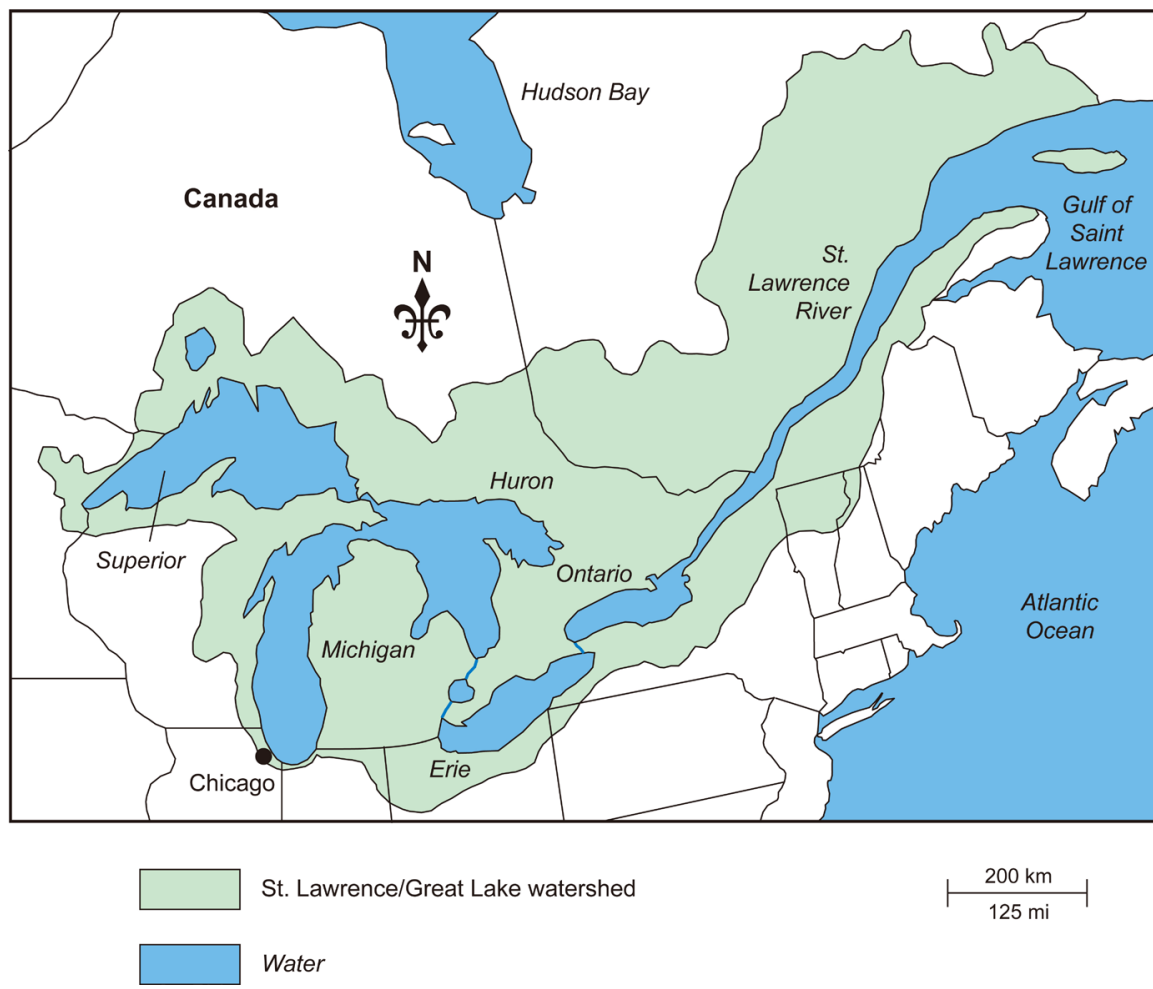

Figure 21. Map of the Great Lakes, the St. Lawrence River, Gulf of Saint Lawrence. Map by Mic Greenberg. Permission to re-print map from JWARP.

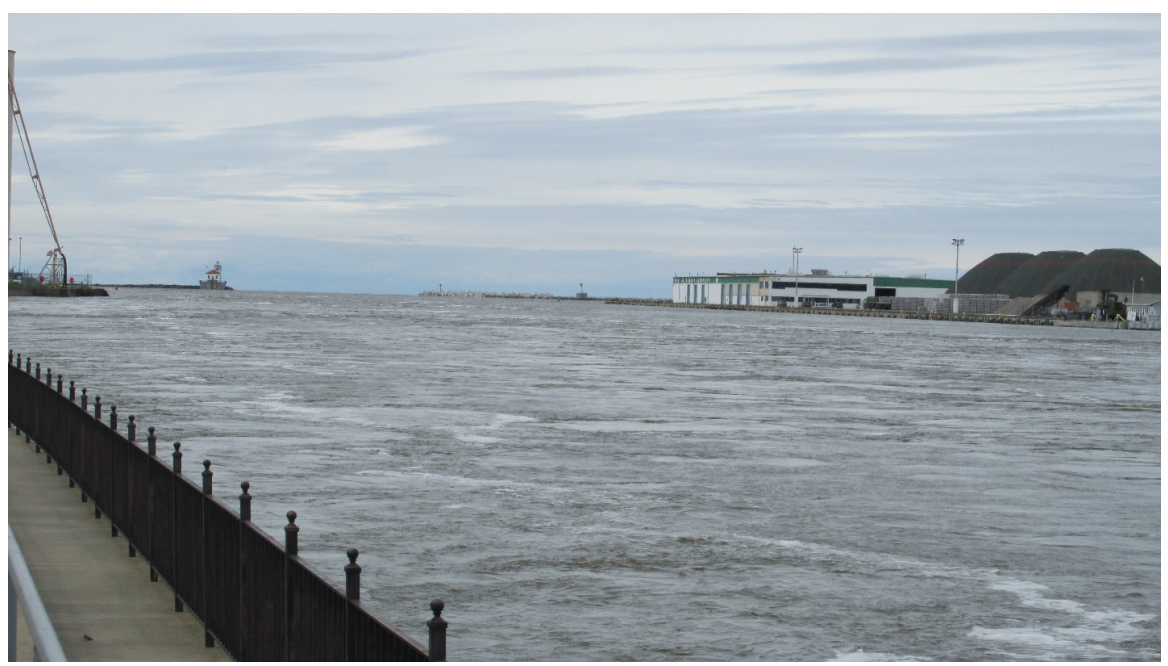

Figure 22. The Port of Oswego on the Oswego River at the mouth of Lake Ontario. Photograph taken by Lois Wright Morton.

seen an increase in commercial use.

\subsection{Economic Potential of the Study Location}

\subsubsection{Energy}

There are 38 nuclear power plants and many coal fire power plants in the Great Lakes Basin. The influence of these power plants and the waste they produce, including air pollution, must be considered when determining the impact on the 
Great Lakes Basin. The Great Lakes Basin includes the large Canadian cities of Toronto, Hamilton, London, St. Catharines, Niagara, and Oshawa.

\subsubsection{Lake Effects}

Lake effect snowfalls are well known by residents living on the shores of the Great Lakes. In the fall and winter, the lakes often have no icepack. The prevailing winds from the west pick up moist air from the lake surface, which is slightly warmer in relation to the cold surface winds [5]. As moist air passes over the colder land surface, the moisture produces heavy snow falls on land. Snow belts are found in the United States in Michigan, Ohio, Pennsylvania and New York, and also Ontario, Canada. The Great Lakes also moderate seasonal temperatures as they absorb heat and cool the air in the summer, and radiate heat in the fall. The lakes keep summer temperatures cooler than further inland, and protect against first frost during the season transitional weather.

\subsubsection{Horticulture}

This temperature buffering creates fruit belts further north of where the fruit is traditionally grown. For example, apple and cherry orchards, along with vineyards (Figure 23), can be found along the northern shores of Lake Erie and Lake Ontario. The Niagara Peninsula between Lake Erie and Lake Ontario, as well as the eastern shore of Lake Erie, have many successful wineries because of the moderating lake effect.

\subsubsection{Ecology}

In the 2000s, the Lake Ontario shoreline was $49 \%$ forested and Lake Erie was just $21 \%$ forested. Urbanization and logging are the most extensive land uses on Lake Erie [3]. For the Eastern Great Lakes, safe drinking water, rising water levels,

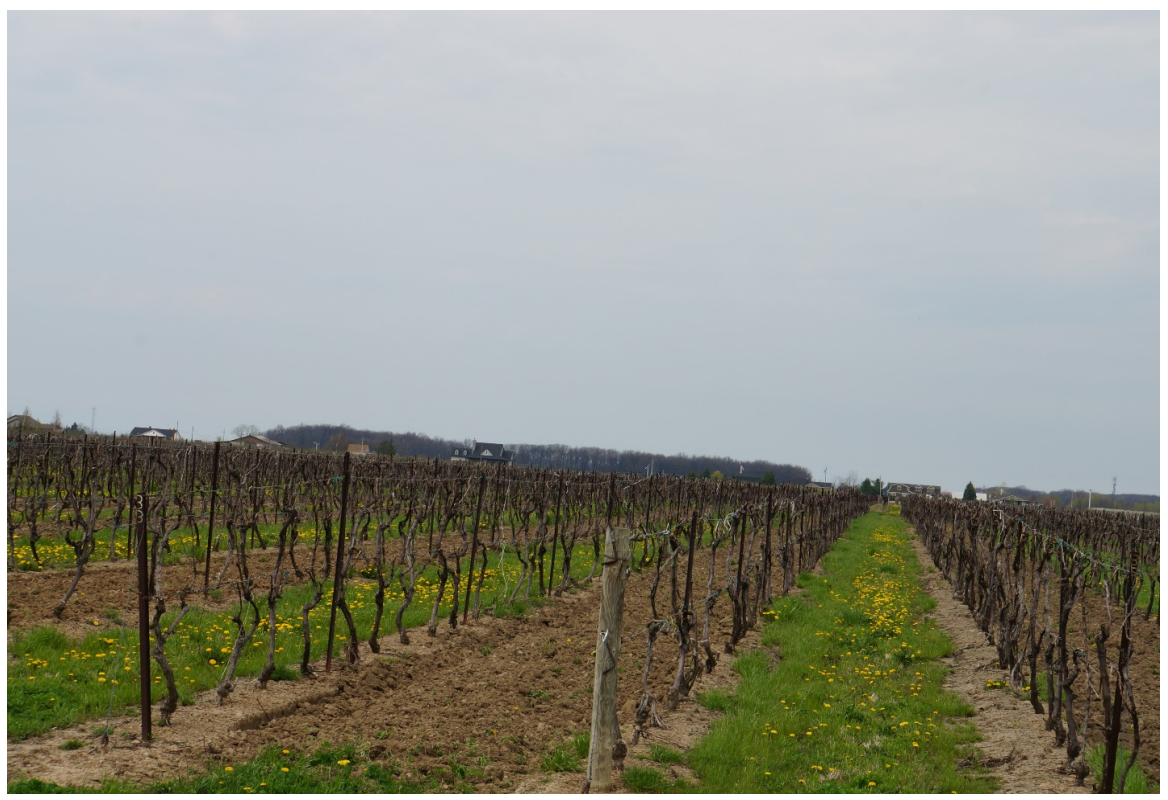

Figure 23. Grape vineyards on the south shore of Lake Ontario. Photograph taken by Lois Wright Morton. 
pollution from industrial and urban wastewater, flooding and shore erosion have become environmental concerns.

\subsubsection{Wildlife-Canada Geese}

The Canada goose (Branta canadensis) is a species of bird with white under its chin, a black head and a brown body [15] [16]. Canada geese are native to arctic regions of North America. Canada geese are migratory and primarily herbivorous. Canada geese are able to adapt to human altered environments, and the Eastern Great Lakes region maintains a very large population. They are found on golf courses, urban parks and parking lots. Canada geese are also hunted as waterfowl in North America. Canadian geese breed in various habits in Canada and the northern United States [6]. They are usually found near fresh water. Canada geese depredate crops, generate noise, leave droppings, engage in territorial behavior, and are adept at begging for food as a result of human hand feeding [17]. They are suspected to be the source of high fecal coliform outbreaks at beaches. Bird strikes by aircraft are common, and Canada geese are second only to turkey vultures in causing fatal airplane crashes when they strike an engine [17].

\subsubsection{Great Lake Levels and Shoreline Erosion}

On May 25, 2018 the Eastern Great Lakes water levels were above their long-term average previous years' May levels. Lake Erie was $47 \mathrm{~cm}$ above while Lake Ontario was $18 \mathrm{~cm}$ above their long term average May level [18]. High lake water levels increase the chances of shore erosion. Storms during high lake level periods have greater bank erosive potential (Figure 24) [5].

Wave action is the wearing away of the shorelines by forces redistributing soil and sand. Waves, rain, water levels, groundwater, wind, ice thrusts [5] and

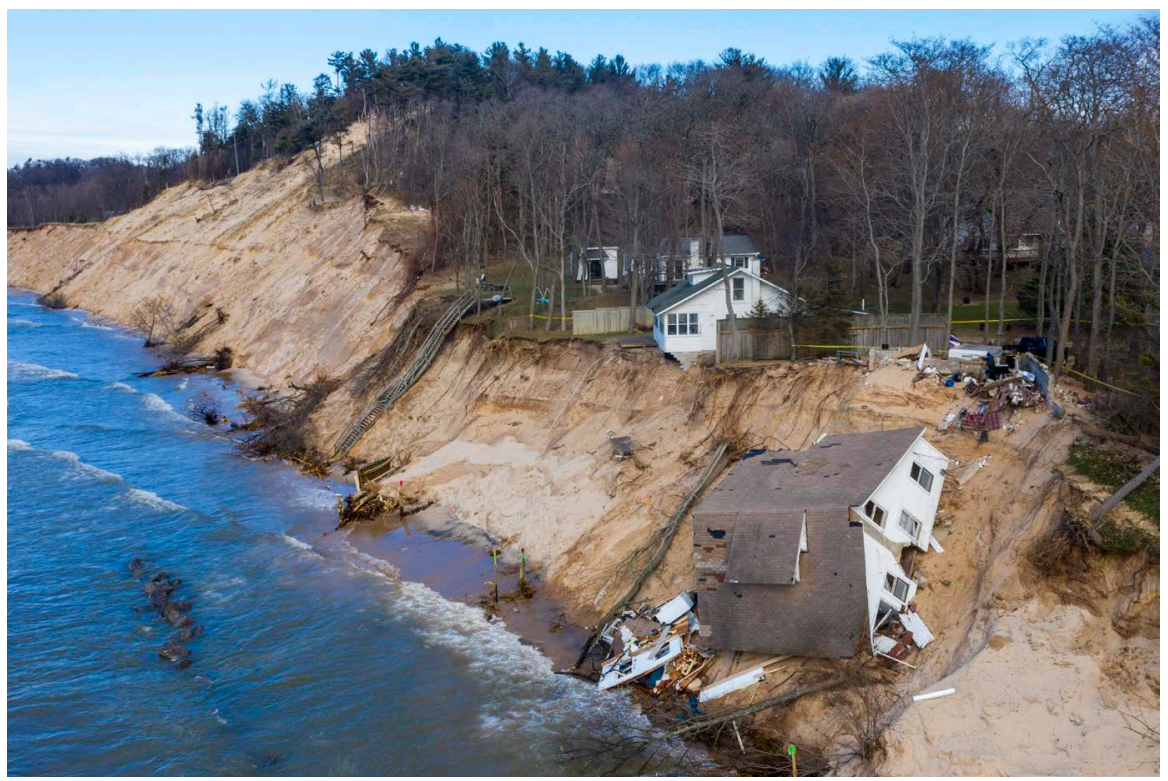

Figure 24. Lake Michigan erosion claims a beach house on January 2, 2020, in White River Township, near Montague, MI (c) 2020 Mlive Media Group. All rights reserved. Used with copyright permission from JWARP [5]. 
people all contribute to retreating shorelines. The Eastern Great Lakes shoreline is actively eroding. Some shoreline areas erode more quickly than others (Figure 24) [5]. These are high risk erosion areas and are eroding at an average rate of 30 $\mathrm{cm}$ or greater per year during the last 20 years. The Michigan Department of Environmental Quality studies the Great Lakes shoreline to identify high risk areas on each Great Lake including Lake Erie and Lake Ontario. Building a home too close to the edge of the bluff puts the structure at risk of falling into the lake [6]. Planned urban development in a high risk area helps prevent the loss of structures. Locating buildings safely back from the bluff may also reduce the need for engineered shore protection and promotes natural shorelines.

\section{Conclusions}

The Eastern Great Lakes Basin consists of the two primary Great Lakes and many secondary lakes that drain directly through tributaries and into the Great Lakes. There are more than 15 million people living in the basin. The Great Lakes are interconnected by a sequence of rivers, lakes, straits and canals that drain to the Atlantic Ocean via the St. Lawrence River. An objective of both the Canadian and the United States governments was to create a navigable waterway called the St. Lawrence Seaway, a maze of canals, locks and channel in the US and Canada that allows ships to travel from the Atlantic Ocean through the Great Lakes. The lakes have been a major highway for trade, transportation and migration.

Historically the Eastern Great Lakes were surrounded by various forest ecoregions. Agriculture, logging, and urbanization have changed land use in the Eastern Great Lakes basin. The Great Lakes shoreline is actively eroding, and additional studies are needed to identify high risk areas. Building too close to the edge of the bluff puts the buildings at risk of falling into the lake. Planned urban development in a high risk area helps to prevent the loss of structures including homes.

The settlement of millions of people into the Eastern Great Lakes via the NYS Barge Canal and St. Lawrence Seaway migration pathways has created environmental and natural resource challenges and risks. These challenges include urban and industrial wastewater disposal [19], shoreline erosion as results of high water levels, building on the shoreline banks, invasive species and flooding.

The current Welland Ship Canal is deteriorating and the $5^{\text {th }}$ Welland Ship Canal is needed and was being planned to the east of the existing canal and would have crossed the Niagara Escarpment in one "super lock". While the design was finalized and the land expropriated, the project never advanced past the initial construction stages before being abandoned. This plan for the $5^{\text {th }}$ Welland Ship Canal needs to be re-activated and constructed in the next 10 years since the current Welland Ship Canal was originally designed to only last until 2030 or for 200 years after the full shipping season in 1830 .

\section{Acknowledgements}

Published with funding support from USDA, NIFA and the Department of Nat- 
ural Resources and approved for publication by the Director of the Illinois Office of Research, College of Agricultural, Consumer, and Environmental Science, University of Illinois, Urbana.

\section{Conflicts of Interest}

The authors declare no conflicts of interest regarding the publication of this paper.

\section{References}

[1] Beeton, A.M. (2020) Great Lakes Lake System North America. Encyclopedia Britannica Inc., Chicago.

[2] Gradu. W. (2007) The Great Lakes. Vancouver: Greyston Books and David Suzuki Foundation. 13, 21-26, 42-43.

[3] Likens, G.E. (2010) Lake Ecosystem Ecology: A Global Perspective. Academic Press, Cambridge, 326.

[4] Bennett, T. and Waszak, M. (1991) State of the Great Lakes: 1997 Annual Report. Diane Publishing, Collingdale, Pennsylvania.

[5] Olson, K.R. and Miller, G. (2020) St. Lawrence Seaway: Western Great Lakes Basin. Journal of Water Resource and Protection, 12, 637-656. https://doi.org/10.4236/jwarp.2020.128039

[6] Olson, K.R. and Suski, C. (2020) St. Lawrence Seaway: St. Lawrence River and Gulf of Saint Lawrence Estuary. Journal of Water Resource and Protection, 12, 672-691. https://doi.org/10.4236/jwarp.2020.128041

[7] Trigger, B. (1987) The Children of Aataentsic. McGill-Queen's University Press, Kingston and Montreal

[8] Morton, L.W. and Olson, K.R. (2019) Corridor of migration, Navigation, and Innovation: The New York State Canal System. Journal of Soil and Water Conservation, 74, 102A-108A. https://doi.org/10.2489/jswc.74.5.102A

[9] Smith, D.R., King, K.W. and Williams, M.R. (2015) What Is Causing the Harmful Algal Blooms in Lake Erie? Journal of Soil and Water Conservation, 70, 27A-29A. https://doi.org/10.2489/jswc.70.2.27A

[10] Olson, K.R. and Morton, L.W. (2016) Managing the Mississippi and Ohio River Landscapes. Soil and Water Conservation Society, Ankeny, Iowa.

[11] Hennepin, L. (1903) A New Discovery of a Vast Country in America. A.C. McClurg and Company, Chicago.

[12] Porter, P. (1914) Landmarkers of Niagara Frontiers. A Chronology. The Library of Congress, Washington DC.

[13] Encylopedia Britannica (2020) Welland Ship Canal, Canada. Chicago, Illinois.

[14] Wikipedia: The Free Encyclopedia (2020) Welland Canal. Wikimedia Foundation, St. Petersburg, FL.

[15] Hanson, H.C. (1965) The Giant Canada Goose. 2nd Edition, Southern Illinois University Press, Illinois.

[16] Carlson, K. (2011) New York Solves Its Canada Goose Problem by Feeding Them to Pennsylvania's Poor. National Post.

[17] Olson, K.R. and Morton, L.W. (2019) Managing Pymatuning Swampland in Northwestern Pennsylvania: A Personal Story. Journal of Soil and Water Conserva- 
tion, 74, 35A-41A. https://doi.org/10.2489/jswc.74.2.35A

[18] United States Army Corps of Engineers (2015) Great Lake Water Levels. https://www.lre.usace.army.mil/Missions/Great-Lakes-Information/Great-Lakes-W ater-Levels/Water-Level-Forecast/Weekly-Great-Lakes-Water-Levels/

[19] Ontario Ministry of Environment and Energy (1990) Chemicals of Concern in Niagara River Tributaries 1988-1989. Queen's Printer. 